\title{
Offshoring At Acesco Medical Devices
}

\author{
John C. McIntosh, Boise State University, USA
}

\begin{abstract}
The medical device industry is highly profitable and projected to experience double digit growth well into the future. The five top performing American medical device companies offshore some core and non-core value chain activities to realize lower production costs, higher innovation, and faster time to market. This case examines the offshoring decision of Acesco Medical Devices - a medium-size company that produces neurology, orthopedics, and cardiovascular products. It considers the tradeoffs between corporate social responsibility, as it pertains to workforce reductions in the United Sates, and the substantial strategic benefits of offshoring to India.
\end{abstract}

Keywords: Offshoring; Outsourcing; Medical Devices; Corporate Social Responsibility; Strategic Management

\section{INTRODUCTION}

$\varnothing$ im Fraser pondered the proposal to relocate some of Acesco Medical Devices, Inc's activities to India. There are compelling cost savings and attractive new market opportunities from offshoring, but the prolonged U.S. recession and dour domestic political mood are reasons for caution. In particular, exporting high paying R\&D and manufacturing jobs could be construed as yet another example of corporate greed. Nevertheless, recent developments in the industry's competitive and external environments offer powerful reasons to do so. Any decision must balance corporate social responsibility as it pertains to job loss in the U.S. against considerable benefits from offshoring.

Exhibit 1: Financial Data for Selected Medical Device Firms Engaging in Offshoring (2008-2012)

\begin{tabular}{|c|c|c|c|c|c|}
\hline & 2008 & 2009 & 2010 & 2011 & 2012 \\
\hline Sales & \multicolumn{5}{|c|}{ \$ millions } \\
\hline Johnson \& Johnson & 63,747 & 61,897 & 61,587 & 65,030 & 67,224 \\
\hline General Electric & 112,769 & 103,777 & 100,437 & 94,523 & 100,149 \\
\hline Siemens & 77,327 & 76,651 & 75,978 & 73,275 & 78,296 \\
\hline Medtronic, Inc. & 13,515 & 14,599 & 15,817 & 15,933 & 16,184 \\
\hline Baxter International & 12,348 & 12,562 & 12,843 & 13,893 & 14,190 \\
\hline \multicolumn{6}{|l|}{ Net Profit } \\
\hline Johnson \& Johnson & 12,949 & 12,266 & 13,334 & 9,672 & 10,514 \\
\hline General Electric & 17,410 & 11,025 & 11,644 & 14,151 & 13,641 \\
\hline Siemens & 5,886 & 2,497 & 4,068 & 6,321 & 4,590 \\
\hline Medtronic, Inc. & 2,231 & 2,169 & 3,099 & 3,096 & 3,617 \\
\hline Baxter International & 2,014 & 2,205 & 1,420 & 2,224 & 2,326 \\
\hline \multicolumn{6}{|l|}{\begin{tabular}{|l|} 
Net Worth \\
\end{tabular}} \\
\hline Johnson \& Johnson & 42,511 & 50,588 & 56,579 & 57,080 & 64,826 \\
\hline General Electric & 104,665 & 117,291 & 118,936 & 116,438 & 123,026 \\
\hline Siemens & 27,380 & 27,287 & 29,096 & 32,156 & 31,302 \\
\hline Medtronic, Inc. & 11,536 & 12,851 & 14,629 & 15,968 & 17,113 \\
\hline Baxter International & 6,229 & 7,191 & 6,567 & 6,585 & 6,938 \\
\hline Pretax Profit/Sales & \multicolumn{5}{|c|}{$-\%$} \\
\hline Johnson \& Johnson & 26.6 & 25.5 & 27.5 & 19.0 & 20.5 \\
\hline General Electric & 17.0 & 10.0 & 14.1 & 21.3 & 17.4 \\
\hline Siemens & 3.7 & 5.1 & 7.6 & 13.1 & 9.3 \\
\hline Medtronic, Inc. & 21.3 & 17.8 & 25.1 & 23.4 & 25.6 \\
\hline Baxter International & 19.8 & 21.8 & 14.7 & 20.2 & 20.4 \\
\hline
\end{tabular}

Source: Company Annual Financial Statements 
The global medical device industry is lucrative with 2012 revenues of $\$ 350$ billion that are expected to grow to $\$ 440$ billion by 2018 . The U.S. is the largest medical device market with 2012 sales of $\$ 120.4$ billion projected to grow to $\$ 156.8$ billion in 2018 . The top thirty-two American companies each enjoy more than $\$ 1$ billion in annual revenue and account for approximately $40 \%$ of the world market (Frost and Sullivan, 2012). American firms also face favorable domestic developments, such as a burgeoning number of Baby Boomers who consume significant amounts of healthcare, especially in the later stages of life; strong sales despite the prolonged recession; and increased demand driven by the large number of newly insured under Obamacare. The industry is lucrative and firms, engaged in offshoring experienced strong performance (Exhibit 1).

\section{COMPANY BACKGROUND}

Acesco Medical Devices, Inc. is an original equipment manufacturer focused on the neurology, orthopedics, and cardiovascular segments. All three exhibited double digit growth rates that are expected to continue into 2018 (Transparency Market Research, 2012). The company, lagging industry trends, manufactures exclusively within the United States. By using Food and Drug Administration (FDA) approved domestic contractors to create components and subassemblies. Acesco reduces costs and time-to-market. This frees it to focus on developing new and innovative products - an increasingly important competitive dimension. Additionally, domestic contractors tend to be more reliable and trustworthy than foreign counterparts. Some firms contracting with Chinese manufacturers experienced catastrophic quality control issues and technology leakage (Sun, 2012). Despite those advantages, as product designs become standardized and foreign markets become more attractive, offshoring becomes a competitive necessity. Foreign subcontractors not only offer cost and time savings but also bring deep knowledge of the regulatory environment in their home markets and the markets they sell to.

Although Acesco's performance is strong, recent developments pose uncertainties for the U.S. market. The Patient Protection and Affordable Care Act of 2010 will impose a 2.3\% excise tax, effective in 2013, on total company revenues, regardless of profitability. In other words, a firm may incur losses and still be liable for the excise tax. Proposed reforms to the FDA-approval process, expected to hamper innovation and raise costs, will cause firms to locate some activities in countries with lower labor costs and favorable regulation. Furthermore, increasingly stringent Medicare reimbursement requirements, smaller reimbursements, and other cost-cutting pressures will make emerging markets, such as Brazil and China, attractive (Bain and Company, Inc., 2012).

\section{MEDICAL DEVICE INDUSTRY SWOT ANALYSIS}

\section{Strengths}

Research Infrastructure and Venture Funding

Medical research and teaching institutions in the U.S. rank among the best in the world. There are 141 accredited medical schools, approximately 350 major teaching hospitals, and 51 Veterans Affairs medical centers (Association of American Medical Colleges, 2013). Close collaboration between research labs, hospitals and venture capitalists has helped rapidly commercialize innovations. Indeed, recent landmark technologies, such as implantable cardiac defibrillators, arose from such collaboration (National Venture Capital Association, 2013).

\section{Market Size and Strength of American Companies}

The U.S. is the largest market for medical devices with sales of \$120.4 billion in 2012. The top thirty-two American companies each enjoy more than $\$ 1$ billion in annual revenue. Additionally, American companies dominate the $\$ 350$ billion global medical device industry with approximately $40 \%$ of the market (Frost and Sullivan, 2012).

\section{Consumer Trends}

The ubiquity of mobile devices, such as smartphones and tablets, is driving the consumerization of medical devices. With medical associations and health care providers posting information on the Web, patients are now 
making treatment decisions in conjunction with healthcare providers. This trend creates opportunities for medical companies that can produce new devices and the necessary software to streamline transfer of diagnostic results to Internet and mobile reporting platforms (West, 2012).

\section{Weaknesses}

Regulation

A recent study comparing the FDA and European Medicines Agency (EMA) device approval processes reported that the FDA's complex regulation and excessive bureaucracy hindered innovation and decreased American firms' competitiveness in the global marketplace. The study noted that the FDA review process is almost twice as long as that of the EMA with a six-month mean review time in the U.S. compared to three months in Europe. Short review times are important because regulatory requirements play a significant role in manufacturers' decisions to develop new products. Firms in countries with simpler and more efficient regulatory approval processes are quicker to market and reap first mover advantages (Boston Consulting Group, 2012).

\section{Shrinking STEM Pool}

The U.S. faces a substantial dearth of individuals with science, technology, engineering, and math skills (STEM). This shortfall is partly offset by the $85,000 \mathrm{H1B}$ visas offered to foreign nationals with STEM backgrounds (Microsoft, Inc., 2013). The I-Squared or Immigration Innovation Act proposes to raise the cap to 115,000 visas with annual increases to a maximum of 300,000. The bill is currently generating substantial controversy because of persistent U.S. underemployment.

\section{No Permanent R\&D Tax Credit}

The R\&D Tax Credit offers companies an incentive to invest in high risk research that may result in viable products many years in the future. In its current form, the R\&D tax credit has been temporarily extended since 1981. Historically it has generated $\$ 2$ of economic growth for every $\$ 1$ granted, created high paying jobs, increased productivity, and established the foundation for American competitiveness in a variety of global industries. Prior to 1991, the United States was preeminent among OECD nations in the effectiveness of the R\&D tax credit but by 2008 had fallen to 17th. Many countries worldwide use permanent tax incentives to encourage domestic R\&D. This tax credit creates an advantage for foreign firms (Deloitte, Touche, Tohmatsu Limited, 2013).

\section{Opportunities}

Burgeoning and Aging Populations

The U.S. population is mature with a median age of 36.9 years and $13.1 \%$ of the population 65 and over (U.S. Census Bureau, 2012). Other developed, high-income economies are also aging. Japan, for example, has a median age of 45 with $22.9 \%$ of the population age 65 and over (Japan Statistical Yearbook, 2012). The global population is projected to rise to 9 billion by 2050. Of this number, $15 \%$ or 1.35 billion people will be age sixty and over (United Nations Department of Economic and Social Affairs Population Division, 2004). This bodes well for the industry because the elderly consume a disproportionate amount of health care resources.

\section{Emerging Economies}

Emerging markets will become more important as U.S. regulations and increasingly stringent Medicare reimbursements erode margins. As emerging economies prosper and their populations age, demand will increase (Transparency Market Research, 2012). In addition, less stringent regulations in Brazil and India will likely cause the medical device industry to follow the model of consumer product firms which use emerging markets as a laboratory to develop low cost products that are subsequently sold in a large number of other markets. 


\section{Threats}

\section{Medical Reimbursements}

Reimbursements, which comprise a large percentage of revenue for medical device manufacturers, are expected to become more difficult to obtain. As employers, governments, and private party payers shift a larger percentage of healthcare costs to individuals and providers, device manufacturers will likely experience a decline in revenue (White \& Ginsburg, 2012). In contrast, emerging economies, such as Brazil, India, and China, are expected to offer easier reimbursement terms.

\section{Shifts in Venture Industry Focus}

Many medical technology innovations are incubated in startups that are later acquired by established companies with resources to implement large-scale rollouts. Emerging markets are increasingly attractive to American venture capital because of higher economic growth rates, a strong desire for external investment, and favorable regulation. The U.S. market is less attractive because of complex and cumbersome regulations, difficulty in obtaining reimbursements, and an administration that favors greater regulation. Emerging markets, such as China and India, offer stronger growth, a comparatively streamlined medical device approval process requiring less time and money and large talent pools with vital STEM skills. It is likely that growing venture investments outside the U.S. will give rise to many startup device manufacturers that will be acquired by large medical device companies seeking to fill their product pipelines (National Venture Capital Association, 2013).

\section{OFFSHORING IN INDIA}

India offers a large pool of technical talent with over 300,000 engineers and 150,000 software developers graduating every year. Those engineers, paid an average of $18.3 \%$ of an American counterpart, represent a substantial cost advantage to firms engaged in offshoring (Pore, et al, 2008). India's highly educated, English speaking labor force is also able to develop software solutions, create new hardware designs, and engage in research and development. They are also likely to create integrated software platforms that facilitate transfer of diagnostic results from medical devices to Internet or mobile platforms used by patients. Industry experts believe that delegating product development, design, and manufacturing to contractors or foreign subsidiaries will reduce costs, truncate the product development cycle, and shorten time-to-market.

\section{Offshoring Political Considerations}

Although the savings and competitive advantages from offshoring are considerable, Fraser understood that the sluggish post-2008 economy put the nation in a dour mood. Public debate over corporate America's greed, hollowing out of the nation's industrial base, and strong corporate performance despite anemic job growth, are reasons for concern. Offshoring, coincidentally, would require Acesco to temporarily locate some foreign researchers and engineers to the U.S. where they would be trained by workers they are replacing. The company would likely face negative publicity that could tarnish its reputation and potentially invite a backlash.

Exhibit 2: U.S. Employment in Selected Manufacturing Industries (2006-2012)

\begin{tabular}{|l|c|c|c|c|c|c|}
\hline & \multicolumn{2}{|c|}{ U.S. Labor Force } & \multicolumn{2}{c|}{ Computer and Electronic Products } & \multicolumn{2}{c|}{ Electrical Equipment and Appliances } \\
\cline { 2 - 7 } & $\mathbf{( 0 0 0 s )}$ & $\mathbf{\%}$ & $\mathbf{( 0 0 0 )}$ & $\mathbf{\%}$ & $\mathbf{( 0 0 0 s )}$ & \% \\
\hline $\mathbf{2 0 0 6}$ & 144,417 & 100.0 & $1,307.5$ & 100.0 & 432.7 & 100.0 \\
\hline $\mathbf{2 0 0 7}$ & 146,050 & 101.1 & $1,272.5$ & 97.3 & 429.4 & 99.2 \\
\hline $\mathbf{2 0 0 8}$ & 145,373 & 100.6 & $1,244.2$ & 95.1 & 424.3 & 98.0 \\
\hline $\mathbf{2 0 0 9}$ & 139,894 & 96.8 & $1,136.9$ & 86.9 & 373.6 & 86.3 \\
\hline $\mathbf{2 0 1 0}$ & 139,077 & 96.3 & $1,094.6$ & 83.7 & 359.5 & 83.1 \\
\hline $\mathbf{2 0 1 1}$ & 139,882 & 96.8 & $1,103.5$ & 84.3 & 366.1 & 84.6 \\
\hline $\mathbf{2 0 1 2}$ & 142,469 & 98.6 & $1,093.7$ & 83.6 & 370.1 & 85.5 \\
\hline
\end{tabular}

Source: Bureau of Labor Statistics, data not seasonally adjusted

American job losses have fallen disproportionately on manufacturing and despite improved employment in 2012, manufacturing still lagged behind the overall economy. Exhibit 2 compares changes in employment between 
2006 and 2012. Overall U.S. employment is compared to that of two high margin manufacturing industriescomputers and electronics (C\&E) and electrical equipment and appliances (E\&A). An examination of the post-2008 crash shows overall U.S. employment in 2009 fell 3.2\% relative to the 2006 baseline. During the same period, employment in C\&E declined $13.1 \%$ while E\&A fell 13.7\%. By 2012, overall U.S. employment was just $1.4 \%$ lower than 2006 while C\&E declined $16.4 \%$ and E\&A fell $14.5 \%$.

Although conventional wisdom asserts that job losses in manufacturing would be offset by new jobs created in the service sector, it presents an incomplete picture of the impact on workers. Exhibit 3 depicts earning patterns of American workers who lost jobs between January 2009 and December 2011 and subsequently found employment in 2012. Of the 3,003,000 unemployed workers, 630,000 (20.9\%) found jobs that paid $20 \%$ or less than their previous wage; $538,000(17.9 \%)$ found jobs with wages equal or above, but within $20 \%$ of their previous salary, and $352,000(11.7 \%)$ were hired at $20 \%$ or more than their previous income. The picture for durable goods manufacturing - the category that encompasses medical devices - is less favorable. Of 457,000 workers who lost jobs, $125,000(27.3 \%)$ found jobs that paid $20 \%$ or less than their former wage; 53,000 (11.5\%) found jobs equal or above, but within $20 \%$ of their pre-unemployment wage; and 48,000 (10.5\%) were hired at $20 \%$ or more than their prior wage. The numbers suggest that workers in durable goods manufacturing did not fare as well as the average for all employment categories.

With U.S. manufacturing employment lagging behind the overall economy, high profits, buoyant device company stock prices, and substantial strategic advantages from offshoring, Fraser's decision must tread a careful path between future opportunities and corporate social responsibility.

Exhibit 3: Displaced U.S. Workers (1) Who Lost Full-Time, Tenured* Wage and Salary Jobs between January 2009 \& December 2011 and were Re-employed in January 2012 by Industry of Lost Job and (2) Earnings Level of New Job (1,000's)

\begin{tabular}{|c|c|c|c|c|c|}
\hline $\begin{array}{c}\text { Industry Of Worker Of Lost } \\
\text { Job }\end{array}$ & Total & $\begin{array}{l}\text { 20\% Or More } \\
\text { Below }\end{array}$ & $\begin{array}{r}\text { Below, But } \\
\text { Within 20\% }\end{array}$ & $\begin{array}{l}\text { Equal Or Above, } \\
\text { But Within 20\% }\end{array}$ & $\begin{array}{c}20 \% \text { Or More } \\
\text { Above }\end{array}$ \\
\hline $\begin{array}{l}\text { Total Who Lost Full-Time } \\
\text { Wage \& Salary Jobs }\end{array}$ & 3,003 & 630 & 408 & 538 & 352 \\
\hline $\begin{array}{l}\text { Mining, Quarrying, and Oil and } \\
\text { Gas Extraction }\end{array}$ & 15 & 12 & --- & --- & --- \\
\hline Construction & 393 & 89 & 49 & 64 & 43 \\
\hline Manufacturing & 645 & 171 & 108 & 87 & 64 \\
\hline Durable Goods & 457 & 125 & 74 & 53 & 48 \\
\hline Nondurable Goods & 188 & 46 & 34 & 34 & 16 \\
\hline Transportation and Utilities & 139 & 22 & 26 & 15 & 20 \\
\hline Wholesale and Retail Trade & 368 & 84 & 42 & 77 & 52 \\
\hline Information & 95 & 27 & 14 & 8 & 10 \\
\hline Financial Activities & 255 & 52 & 29 & 46 & 27 \\
\hline $\begin{array}{l}\text { Professional and Business } \\
\text { Services }\end{array}$ & 373 & 56 & 60 & 93 & 36 \\
\hline Education and Health Services & 257 & 29 & 30 & 67 & 21 \\
\hline Leisure and Hospitality & 174 & 25 & 17 & 31 & 22 \\
\hline Other Services & 91 & 20 & 10 & 18 & 11 \\
\hline $\begin{array}{l}\text { Government Wage and Salary } \\
\text { Workers }\end{array}$ & 138 & 30 & 13 & 22 & 33 \\
\hline
\end{tabular}

Source: Bureau of Labor Statistics, data not seasonally adjusted. *Tenured refers to 3 or more years on job lost because of plant or company closing, insufficient work, or abolition of position or shift.

\section{AUTHOR INFORMATION}

John McIntosh is an associate professor of entrepreneurship and strategy at Boise State University. His research focuses on lean startups, rapid prototyping, and strategic management of technology firms. He has published in the Journal of Management Issues, Journal of Applied Business Research, and International Journal of Mobile Communications. E-mail: $\underline{\text { Johnmcintosh@Boisestate.edu }}$ 


\section{REFERENCES}

1. Association of American Medical Colleges. (2013). AAMC Data Book: Medical Schools and Teaching Hospitals by the Numbers 2013. Washington, DC.

2. Bain and Company, Inc. (2012). Global Healthcare Private Equity Report 2012. Boston, MA.

3. Boston Consulting Group. (2012). Regulation and Access to Innovative Medical Technologies: A comparison of the FDA and EU Approval Processes and their Impact on Patients and Industry. Boston, MA. Retrieved from http://www.eucomed.org/uploads/Modules/Publications/2012_bcg_report_regulation_and_access_to_innov ative medical technologies.pdf

4. Deloitte, Touche, Tohmatsu Limited. (2013). 2013 Global Survey of R\&D Tax Incentives. Seattle, WA. Retrieved from http://www.deloitte.com/view/en_US/us/Services/tax/global-business-tax/r-and-d-andgoverment-incentives/Research-and-Development-FederalTax/dbedb490ae9dd310VgnVCM1000003256f70aRCRD.htm

5. $\quad$ Frost and Sullivan (2012). 2012 United States Medical Devices Outlook (NB3E-54). Mountain View, CA.

6. Japan Statistical Yearbook. (2012). Population by Age. Tokyo, Japan. Retrieved from http://www.stat.go.jp/english/data/nenkan/1431-02.htm

7. Microsoft, Inc. (2013). A National Talent Strategy: Ideas For Securing U.S. Competitiveness and Economic Growth. Redmond, WA. Retrieved from http://www.microsoft.com/enus/news/download/presskits/citizenship/MSNTS.pdf

8. National Venture Capital Association (2013). Patient Capital 3.0-Confronting the Crisis and Achieving the Promise of Venture-Backed Medical Innovation. Arlington, VA.

9. Pore, M., Yu, P., Lakshman, P., \& Cooney, C.L. (2008). Offshoring in the Pharmaceutical Industry. In The Offshoring of Engineering: Facts, Unknowns, and Potential Implications (pp. 103-124). The National Academies Press, Washington, DC.

10. Sun, P. (2012). Medical Device Regulation in China and the US: A Comparison and A Look Forward. Intersect, 5(1) 1-16.

11. Transparency Market Research (2012). Medical Devices Outsourcing Market-Global Industry Size, Market Share, Trends, Analysis, and Forecast 2012-2018. Albany, N.Y.

12. United Nations Department of Economic and Social Affairs Population Division. (2004). World Population to 2300. New York, NY. Retrieved from http://www.un.org/esa/population/publications/longrange2/WorldPop2300final.pdf

13. U.S. Census Bureau. (2012). National Totals: Vintage 2012. Washington, DC. Retrieved from http://www.census.gov/popest/data/national/totals/2012/index.html

14. West, D. (2012). How Mobile Devices are Transforming Healthcare. Center for Technology Innovation at Brookings. Washington, DC.

15. White, C. \& Ginsburg, P. B. (2012). Slower Growth in Medicare Spending - Is This the New Normal? New England Journal of Medicine, 366:1073-1075. 